\title{
Decontamination of Gutta-percha Cones employed in Endodontics
}

\author{
Clairde S. Carvalho', Moara S. C. Pinto', \\ Samuel F. Batista', Patrick V. Quelemes², \\ Carlos A. M. Falcão', Maria A. A. L. Ferraz \\ ' Universidade Estadual do Piauí, Coordenação Odontologia, \\ Parnaíba, Piauí, Brasil \\ 2 Universidade Federal do Piauí, Mestrado em Odontologia \\ Teresina, Piauí, Brasil
}

\begin{abstract}
The gutta-percha cones used in endodontic treatment are produced in aseptic conditions and their composition includes zinc oxide, which is responsible for antibacterial activity. However, there is the possibility of microbial contamination by manipulation, aerosol or during storage. Although several chemical agents have been tested for their decontamination, there is no consensus on the best disinfection protocol to be used. The aim of this study was to evaluate the decontamination of gutta-percha cones contaminated with the bacteria Enterococcus faecalis, by using chlorhexidine digluconate (CHX) and sodium hypochlorite $(\mathrm{NaClO})$ at different concentrations for short exposure times. For this purpose, gutta-percha cones (size 40) were selected at random from a sealed box and immersed for 1
\end{abstract}

min in a microbial suspension. Then they were immersed in specific Petri dishes for different groups containing: $\mathrm{CHX} 2 \%$, $\mathrm{NaClO} 1 \%$ or $\mathrm{NaClO} 2.5 \%$ for $30 \mathrm{~s}$ or $1 \mathrm{~min}$, and subsequently placed in tubes containing BHI broth. After incubating the tubes for $48 \mathrm{~h}$, it was observed that $1 \%$ and $2.5 \% \mathrm{NaClO}$ and $2 \% \mathrm{CHX}$ were effective for decontaminating the cones at those exposure time intervals. Microbial growth was detected in one of the replicates of the group with CHX applied for $30 \mathrm{~s}$. To prevent the possibility of failures at this stage, the exposure time of gutta-percha cones to the decontaminating agent should not be reduced.

Received: October 2019; Accepted: March 2020.

Keywords: gutta-percha, decontamination, enterococcus faecalis.

\section{Descontaminação de cones de guta-percha empregados em endodontia}

\section{RESUMO}

Os cones de guta-percha utilizados no tratamento endodôntico são produzidos em condições assépticas e possuem óxido de zinco em sua composição, responsável pela atividade antibacteriana. No entanto, existe a possibilidade de contaminação microbiana por manipulação, aerossol ou seu armazenamento. Embora vários agentes químicos já tenham sido testados para sua descontaminação, não há consenso sobre o melhor protocolo de desinfecção a ser usado. Nosso objetivo foi avaliar a descontaminação de cones de guta-percha contaminados com a bactéria Enterococcus faecalis, utilizando digluconato de clorexidina ( $\mathrm{CHX}$ ) e hipoclorito de sódio $(\mathrm{NaClO})$ em diferentes concentrações e tempos de exposição curtos. Para esse fim, 40 cones de guta-percha foram selecionados aleatoriamente, de uma caixa selada e imersos por $1 \mathrm{~min} \mathrm{em}$

\section{INTRODUCTION}

The success of endodontic therapy is strictly related to the careful aseptic performance of all its phases, including opening, cleaning, disinfecting, modeling and subsequent sealing of the entire root canal system $^{1-3}$. However, during this process there may uma suspensão microbiana. Em seguida, foram imersos em placas de Petri específicas para diferentes grupos contendo: $\mathrm{CHX} 2 \%, \mathrm{NaClO} 1 \%$ ou 2,5\%, nos tempos de exposição de $30 \mathrm{~s}$ e lmin e subseqüentemente imersos em tubos contendo caldo BHI. Após incubação dos tubos por $48 \mathrm{~h}$, observou-se que $\mathrm{NaClO} 1 \%$ e 2,5\% e CHX 2\% foram eficazes para a descontaminação dos cones nesses intervalos de tempo de exposição. Em uma das réplicas do grupo com $\mathrm{CHX}$ aplicado por 30 s foi detectado crescimento microbiano. O tempo de exposição dos cones de guta-percha ao agente de descontaminação não deve ser reduzido para evitar a possibilidade de falhas nesse estágio.

Palavras-chave: guta-percha, descontaminação, enterococcus faecalis.

be failures in instrumentation, infiltration of bacteria present in saliva and/or use of contaminated instruments and/or materials ${ }^{4}$.

Microorganisms may still persist after biomechanical preparation due to variations in root canal internal anatomy or as a result of the defense mechanisms 
of the microorganisms themselves, so the need for good filling and sealing of the root canal system is imperative ${ }^{5,6}$.

For an adequate sealing procedure, the obduration material should ensure three-dimensional filling of the root canal system, thereby preventing bacterial percolation and the appearance or maintenance of periapical lesions ${ }^{7}$.

Gutta-percha cones have several properties that make them an excellent material for canal obturation, including biocompatibility, size stability, radiopacity, thermoplasticity, easy removal from the root canal ${ }^{8,9}$ and antibacterial activity ${ }^{10}$.

These cones are based on a polymer obtained from the coagulation of latex produced by trees in the Sapotaceae family, mainly Palaquiumgutta. Commercial gutta-percha cones consist of an inorganic part containing barium sulphate $(\mathrm{BaSO} 4)$ and zinc oxide $(\mathrm{ZnO})$ and an organic part composed of waxes/resins and gutta-percha. Their percentage content varies according to the manufacturer, and will directly influence rigidity, tensile strength, brittleness and radiopacity ${ }^{10}$.

Although they are produced under aseptic conditions and contain about $69.8-81.9 \%$ of zinc oxide, which is responsible for the antibacterial activity ${ }^{10}$, there is still a chance of contamination by manipulation, aerosol or storage ${ }^{8,11}$.

Gutta-percha cones cannot withstand sterilization processes, so they must undergo a decontamination step to ensure the maintenance of the aseptic chain. Although several chemical agents have been tested, there is no consensus in the literature on which is the best protocol to disinfect these materials $\mathrm{s}^{2,3,12,13}$. Under these circumstances, the use of $\mathrm{NaOCl}$ for rapid decontamination of gutta-percha cones was proposed by Senia et al. ${ }^{14}$, who demonstrated that when contaminated with the bacteria Staphylococcusepidermidis, Corynebacteriumxerosis, Escherichia coli and Enterococcus faecalis, they were decontaminated after immersion in Clorox ${ }^{\circledR}$ (5.25\% sodium hypochlorite) for 30,45 and 60 seconds.

Another chemical agent that has been widely applied in endodontics is chlorhexidine digluconate, which was first used for root canal irrigation in 1964 , and is currently therapeutically categorized as having long-acting antimicrobial action, especially against E. faecalis, being a topical antiseptic anddisinfecting agent ${ }^{15,16}$.
The aim of this paper is to verify the efficacy of decontamination protocols of gutta-percha cones employed in root canal obturation, using $\mathrm{NaOCl}$ and chlorhexidine digluconate as disinfecting agents, with variations in their concentrations and short times of action.

\section{MATERIALS AND METHODS}

This was an exploratory, observational laboratory study with a qualitative approach. E. faecalis (ATCC 29212) was inoculated on Brain Heart Infusion (BHI) agarin Petri dishes and incubated for 24 hours at $37^{\circ} \mathrm{C}$ under aerobic conditions. After that, bacterial colonies were collected with the aid of a platinum loop and inoculated in sterile saline solution $(0.9 \% \mathrm{w} / \mathrm{v} \mathrm{NaCl})$ until a turbidity of 0.5 on the McFarland scale $\left(1-2 \times 10^{8} \mathrm{CFU} / \mathrm{ml}\right)$ was obtained. This suspension was used to contaminate gutta-percha cones.

Thirty-two size 40 gutta-percha cones (Dentsply) ${ }^{\mathrm{TM}}$ were used. The sealed package of cones was opened inside a laminar flow hood previously sterilized by UV light and the cones were removed in random order with the aid of sterile tweezers. Each cone was immersed completely in $6 \mathrm{~mL}$ of microbial suspensionin Petri dishes for 1 minute to ensure contamination. For the subsequent disinfection process, the cones were removed from the contaminated solution with the aid of sterile tweezersand transferred to Petri dishes (one for each group) containing the disinfecting solutions to be evaluated. Six groups were formed, each containing 4 cones (experiment performed in quadruplicate) individually immersed in solutions of $2 \%$ chlorhexidine digluconate (CHX), 1\% sodium hypochlorite $(\mathrm{NaOCl}$ or $\mathrm{NaClO})$ or $2.5 \%$ sodium hypochlorite, at exposure times of $30 \mathrm{~s}$ and $1 \mathrm{~min}$ each. After this time, the cones were removed from the disinfecting solution and immersed for 10 seconds in sterile distilled water to remove excess disinfectant (Table 1). Finally, the cones were placed inside threaded tubes containing $3 \mathrm{~mL}$ BHI broth supplemented with $1 \%$ yeast extract and incubated for $48 \mathrm{~h}$ in an oven at $37^{\circ} \mathrm{C}$ under aerobic conditions. After this time, the results were recorded based on turbidity (bacterial growth) or absence of turbidity in the culture medium. A positive control group, to attest to E. faecalis viability, was prepared by immersing contaminated cones only in saline solution. A negative control group, to certify that the cones in the sealed box 
were sterile, was prepared by removing cones from the carton using sterile tweezers and placing them immediately in the culture medium.

Nonparametric Kruskall-Wallis and Mann-Whitney tests were used for statistical evaluation of results.

\section{RESULTS}

After a $48 \mathrm{~h}$ incubation period at $37^{\circ} \mathrm{C}$ under aerobic conditions, bacterial growth was observed in all tubes of the positive control group, indicating that the bacteria were viable and in sufficient quantity for growth in the tubes, as well as the effectiveness of the culture medium in providing nutrients for growth and multiplication. In the negative control group, no turbidity occurred, evidencing that the cones coming from the sealed box were without microbial contamination.

There was no bacterial growth in three of the four incubated samples in group G1 (CHX 2\% -30s), but turbidity of the medium was observed in one of the replicates. In group G2 (CHX 2\%-1min, with the same chemical solution but longer exposure time than G1), effective decontamination was observed in all samples (Table 2). In groups G3, G4, G5 and G6, which corresponded to the application of sodium hypochlorite, no bacterial growth was observed in any of the four samples in each group (Table 3).
In order to identify whether there are statistically significant differences regarding the presence of microbiological contamination in the groups, nonparametric tests were performed, considering the non-normal distribution of the data, ascertained by the significant value of the KolmogorovSmirnov test $(\mathrm{p}<0.001)$. Thus, at first, the Kruskal Wallis test was performed to compare the eight

\begin{tabular}{|c|c|}
\hline Group & Treatment \\
\hline G1 & $\begin{array}{l}\text { Immersion in chlorhexidine digluconate } 2 \% \text { - } \\
30 \text { seconds }\end{array}$ \\
\hline G2 & $\begin{array}{l}\text { Immersion in chlorhexidine digluconate } 2 \% \text { - } \\
1 \text { minute }\end{array}$ \\
\hline G3 & $\begin{array}{l}\text { Immersion in sodium hypochlorite } 1 \% \text { - } \\
30 \text { seconds }\end{array}$ \\
\hline G4 & $\begin{array}{l}\text { Immersion in sodium hypochlorite } 1 \% \text { - } \\
1 \text { minute }\end{array}$ \\
\hline G5 & $\begin{array}{l}\text { Immersion in sodium hypochlorite } 2.5 \% \text { - } \\
30 \text { seconds }\end{array}$ \\
\hline G6 & $\begin{array}{l}\text { Immersion in sodium hypochlorite } 2.5 \% \text { - } \\
1 \text { minute }\end{array}$ \\
\hline Positive control & Immersion in saline solution \\
\hline Negative control & Direct immersion in the culture medium \\
\hline
\end{tabular}

\begin{tabular}{|c|c|c|c|c|}
\hline Sample & $\begin{array}{c}\text { Group } 1 \\
\mathrm{CHX} 2 \%(30 \mathrm{~s})\end{array}$ & $\begin{array}{c}\text { Group } 2 \\
\mathrm{CHX} 2 \%(1 \mathrm{~min})\end{array}$ & Positive Control & Negative Control \\
\hline 1 & 0 & 0 & 1 & 0 \\
\hline 2 & 0 & 0 & 1 & 0 \\
\hline 3 & 0 & 0 & 1 & 0 \\
\hline 4 & 1 & 0 & 1 & 0 \\
\hline
\end{tabular}

\begin{tabular}{|c|c|c|c|c|c|c|}
\hline Sample & $\begin{array}{c}\text { Group } 3 \\
\text { NaCIO 1\% } \\
\text { (30 s) }\end{array}$ & $\begin{array}{l}\text { Group } 4 \\
\text { NaCIO 1\% } \\
\text { (1 min) }\end{array}$ & $\begin{array}{c}\text { Group } 5 \\
\mathrm{NaClO} 2,5 \% \\
(30 \mathrm{~s})\end{array}$ & $\begin{array}{c}\text { Group } 6 \\
\text { NaClO 2,5\% } \\
(1 \mathrm{~min})\end{array}$ & $\begin{array}{l}\text { Positive } \\
\text { Control }\end{array}$ & $\begin{array}{c}\text { Negative } \\
\text { Control }\end{array}$ \\
\hline 1 & 0 & 0 & 0 & 0 & 1 & 0 \\
\hline 2 & 0 & 0 & 0 & 0 & 1 & 0 \\
\hline 3 & 0 & 0 & 0 & 0 & 1 & 0 \\
\hline 4 & 0 & 0 & 0 & 0 & 1 & 0 \\
\hline
\end{tabular}


groups together, finding a statistically significant difference among them $(p=0.01)$, with the highest average for gutta-percha cones in the positive control group, followed by G1 and the other groups. Mann-Whitney tests were performed to compare the groups in pairs considering the different substances and times. No statistically significant difference was found upon comparing groups G1 and $\mathrm{G} 2(\mathrm{U}=6.01 ; \mathrm{p}=0.69) ; \mathrm{G} 3$ and $\mathrm{G} 4 \mathrm{G} 2(\mathrm{U}=$ $8.00 ; \mathrm{p}=1.00)$ and $\mathrm{G} 5$ and $\mathrm{G} 6(\mathrm{U}=8.00 ; \mathrm{p}=1.00)$. Statistical difference was found upon comparing the control groups $(U=10.00 ; p=0.03)$, with the positive control group having the highest average.

\section{DISCUSSION}

Amaralet al. ${ }^{17}$ report that $\mathrm{NaOCl}$ has been widely applied in endodontics in various concentrations in the chemical preparation of root canals and as an effective method to disinfect gutta-percha cones. The high active chlorite content is a predominant factor to maintain product quality, in which decontamination is inversely proportional to concentration. Chlorhexidine has also been used as an antimicrobial solution in endodontic therapy and is indicated for patients who are allergic to $\mathrm{NaOCl}$ or for refractory treatments, in which the use of intracanal medication has not been successful.

According to Gomes et al. ${ }^{18}$, several antiseptic chemicals have been described in the literature but chlorhexidine and $\mathrm{NaOCl}$ have been highlighted because they are considered potent antimicrobial agents.

Rocha et al. ${ }^{19}$ evaluated the decontamination of cones previously contaminated with strains of E. faecalis (alcohol $70 \%$, chlorhexidine $0.12 \%$ and $2 \%, \mathrm{NaClO} 1 \%, 2 \%$ and $2.5 \%$ salinefor $1,2,3,4$ and 5 minutes), and found that all agents were effective in decontamination for one minute or longer. In the positive control group, turbidity was observed, indicating that the bacteria remained viable until the end of the experiment. The negative control tube did not present growth of microorganisms, ensuring the sterility of the cones in that experiment, corroborating our results. A divergent result was observed by Sayãoet al. ${ }^{5}$, who observed that $6.67 \%$ of the cones from sealed or manipulated boxes were contaminated.

Amaralet al. ${ }^{17}$ evaluated the effectiveness of guttapercha and Resilon cone decontamination with the following groups: $\mathrm{NaOCl} 5.25 \%, \mathrm{NaOCl} 2.5 \%$, chlorhexidine $2 \%$ for 1 minute; phenolic glycerin for 24 hours. The agents were effective as decontaminants, although $2 \%$ chlorhexidine was ineffective in $20 \%$ of both gutta-percha and Resilon cones, differing from our study on the 1-minute test time using chlorhexidine $2 \%$, which showed efficacy in $100 \%$ of the samples. However, with reservations for the 30 -second time, in which there was contamination in one replicate, the action of $\mathrm{NaClO}$ corroborates our study in the one-minute test.

Cardoso et al. ${ }^{20}$ tested $1 \% \mathrm{NaOCl}$ and showed that it was efficient for the decontamination of cones contaminated with $E$. faecalis in a contact time of 5 minutes. In the current study, we demonstrated that $1 \% \mathrm{NaOCl}$ is capable of disinfecting in a time frame of 30 seconds. Schmidt et al. ${ }^{3}$ tested the effect of $\mathrm{NaOCl}$ at $2.5 \%$ and chlorhexidine gel at $2 \%$, observing that they could both promote complete elimination of E. faecalis, Candida albicans, and Staphylococcus aureus after 30 seconds of exposure time.

Redmerski et al. ${ }^{2}$ demonstrated that $2 \%$ chlorhexidine digluconatewas effective in the decontamination in 5 min of cones contaminated with $S$. aureus, E. faecalis, E. coli, C. albicans, and spores of $B$. subtilis. In our research, the same solution was effective against $E$. faecalis as from 1 minute exposure time.

There is interest in reducing decontamination time because the surface of gutta-percha cones may change after decontamination with sodium hypochlorite. It is known that $5.25 \% \mathrm{NaOCl}$ causes changes in the topography of gutta-percha cones in 20-minute exposure times and changes in elasticity in only one minute, while $2 \%$ chlorhexidine does not cause structural change in gutta-percha cones ${ }^{21}$.

\section{CONCLUSION}

The results indicated that $1 \%$ and $2.5 \% \mathrm{NaOCl}$ and $2 \%$ chlorhexidine digluconate were effective for the decontamination of gutta-percha cones contaminated with $E$. faecalis, in short contact time intervals of $30 \mathrm{~s}$ and $1 \mathrm{~min}$. It should be recognized, however, that microbial growth was observed in one of the replicates of the CHX experiment applied for 30 s, which provides a warning that the disinfection protocols must still be followed, with special care to not unduly reduce the exposure time to the decontaminating agent. 


\section{FUNDING}

None

\section{CORRESPONDENCE}

Dra. Maria Ângela ArêaLeão Ferraz

Av. São Sebastião, 4638 - Nossa Senhora de Fátima,

Parnaíba, Piauí, Brazil

angela.endo@hotmail.com

and Resilon cones. Oral Surg Oral Med Oral Pathol Oral Radiol Endod 2011; 111:21-24.

12. Siqueira JJF, Pereira CHS, Cerqueira MDO, Lopes HP, Uzeda M. Effectiveness of four chemical solutions in eliminating Bacillus subtilis spores on gutta- percha cones. Endod Dent Traumatol. 1998;19: 124-129.

13. Souza ER, Souza EA, Neto MDS, Pietro RCLR. In vitro evaluation of different chemical agents for the de contamination of gutta-percha cones. Pesqui Odontol Bras 2003; 17:75-77.

URL: https://www.scielo.br/scielo.php?script=sci_arttext\& pid $=$ S1517-74912003000100014

14. Senia ES, Marraro RV, Mitchell JL, Lewis AG, Thomas L. Rapid sterilization of gutta- percha cones with $5.25 \%$ sodium hypochlorite. J Endod 1975; 1:136-140.

15. Zamany ASK, Spangberg LSW. The effect of chlorhexidine as an endodontic disinfectant. Oral Surg Oral Med Oral Pathol Oral Radiol Endod2003;5:578-581.

16. Basrani B, Santos JM, Tjardehane L, Grad H, Gordusys Oet al. Substantive antimicrobial activity in chlorhexidine treated human root dentin. Oral Surg Oral Med Oral Pathol Oral Radiol Endod 2002; 94:240-245.

17. Amaral G, Carraz R, Freitas LF, Fidel SR, Castro AJR. Efetividade de três soluções na descontaminação de cones de guta-percha e de resilon. Rev Bras Odontol 2013; 70:54-58. URL: http://revodonto.bvsalud.org/scielo.php?script=sci arttext\&pid=S0034-72722013000100013

18. Gomes CC, Camoes ICG, Freitas LF, Pinto SS, Saraiva SM, Sambati S. Avaliação do hipoclorito de sódio e da clorexidina na desinfecção de cones de guta-percha. Rev Odontol Univ São Paulo 2010; 22:94-103.

URL: http://publicacoes.unicid.edu.br/index.php/revistada odontologia/article/view/403

19. Rocha EALDSS, Limeira FIRL, Carvalho AVOR, Santos KSA, Medeiros ACD. Avaliação da eficácia de diversas substâncias químicas na descontaminação de cones de gutapercha. Odontol Clín-Cient 2013; 12:35-38.

URL: http://revodonto.bvsalud.org/scielo.php?script=sci arttext\&pid=S1677-38882013000100008

20. Cardoso CL, Redmerski R, Bittencourt NRL, Kotaka CR. Effectiveness of different chemical agents in rapid decontamination of gutta-percha cones. Braz J Microbiol 2010; 31:67-71.

URL: https://doi.org/10.1590/S1517-83822000000100016

21. Valois CRA, Silva LP, Azevedo RB. Structural effects of $\mathrm{NaOCl}$ solutions on gutta-percha cones: atomic force microscopy study. J Endod 2005;749-751. 